\title{
Spatial and temporal rainfall variability and erosivity: Case of the Issen watershed, SW- Morocco
}

\author{
Mohamed Ait Haddou ${ }^{1 *}$, Belkacem Kabbachi $^{1}$, Ali Aydda ${ }^{1}$, Hicham Gougni ${ }^{1}$, and Youssef \\ Bouchriti $^{1}$ \\ ${ }^{1}$ Geosciences and Environment Team (EGE), Department of Geology, Faculty of Sciences, Ibn Zohr \\ University, Agadir, Morocco
}

\begin{abstract}
The Issen basin is a dry area affected by climate variability and desertification. It is located in high spot of Moroccan flora biodiversity that includes argan tree ecosystem as a part of the Western High Atlas (WHA). The objective of this work is to assess rainfall variability and erosivity as determining factors of soil erosion and vegetation cover degradation. The results reveal an arid to superior semi-arid climate where annual rainfall range from $200 \mathrm{~mm}$ in the centre of the Argana corridor, to $500 \mathrm{~mm}$ in the snow-covered northern foothills. The analysis of the 37 years of rainfall data indicate a coefficient of variation Cvis about $67 \%$. The erosivity index presents a high variability range from 34 to more than $81 \mathrm{MJ} . \mathrm{mm} / \mathrm{ha} . \mathrm{h} . \mathrm{yr}$ in the wettest areas, indicating considerable soil erosion. In addition, the basin suffering from severe periods of drought due to the occurrence of the continuous decrease of the accumulated precipitation. Eventually, the rainfall variability and erosivity can affect ecosystem function and services (ecosystem degradation, water availability, etc).
\end{abstract}

\section{Introduction}

The Moroccan country characterized by three different climatic systems; the humid Mediterranean and humid Atlantic climates in the north and the arid Saharan climate in the south [1]. During the last decades, it was affected by a longest dry period which characterized by rainfall decrease and temperatures increase [2]. In fact, $53 \%$ of the total country was affected [3]. The rainfall decrease affects the vegetation cover growth, especially, in the Moroccan High Atlas mountains [4].

The ecosystems and agriculture activities in the semi-arid areas principally depend on the water availability [3]. In fact, the analysis of the rainfall data is crucial for assessing current environmental constraints and for optimal management of the limited water resources [5].In general, the climate change amplify existing risks and generate new ones for natural and human systems [6].

The Issen basin is the largest sub-basin in the right bank of the Souss river which covers an area of $1302 \mathrm{~km}^{2}$ (fig. 1). The Issen river is the most important tributary descending from the Western High Atlas (WHA), and it is a part of the Argana corridor and its annexed

*Correspondingauthor:medaithaddou@gmail.com 
valleys considered as a suitable area to characterize rainfall instability in the High Atlas Mountains [7]. Geologically, the basin cover all Permo-Triassic red sandstone, detrital sandstone and conglomeratic silty sandstone Formations, which including at least $2500 \mathrm{~m}$ of fluvial, lacustrine and clastic deposits and coarse to fine floodplains [8]. Based on the national soil map database (EuDASM) [9], the red mountain forest soils and the brown and red lightly forested podzolic soils with very heterogeneous vegetation coverare developed on the Triassic Formations. The depression between the ancient massif and the western plateaus creates a natural passageway for the air currents which developing a particular and complex climatic conditions [10].

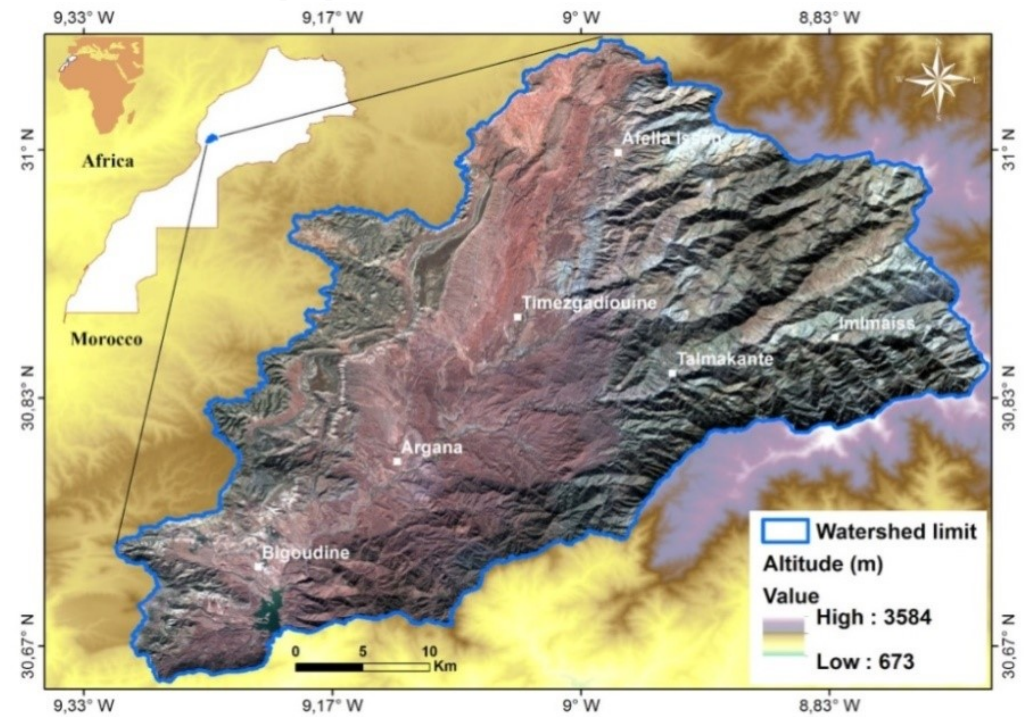

Fig. 1. Study area location.

Topographically, the study area is a sloped land (the average slope is about $33 \%$ ). In addition, the study area is a fragile environment influenced by the pedoclimatic hazards and the frequency of atmospheric disturbances, which affectingthe vegetation distribution (Fig. 2). Also, the study area is characterized by the presence of the argan steppes. Due to the climatic aggressiveness andthe high anthropogenic pressure, the High Atlas mountains and the Issen basin as a part of it suffering from water erosion risks, including soil degradation and flooding $[11,12]$.

The vegetation cover in the Issen basin includes the argan tree (Arganiaspinosa) ecosystems, which is considered as a natural, national and universal heritage, associated with endemic or rare plants serving several applications; aromatic, medicinal, melliferous and pastoral [13]. 


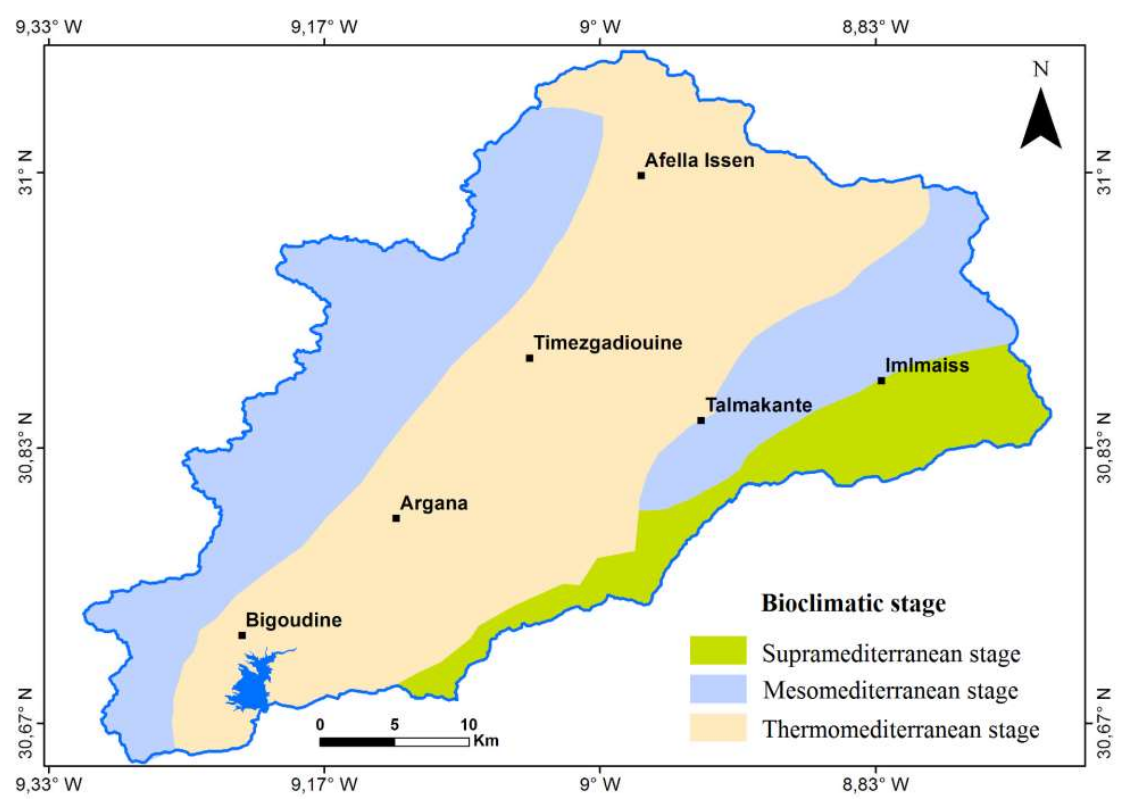

Fig.2.Map shows the bioclimatic zones in the Issen basin [14].

The present study aims to analyse the contemporary spatial and temporal variability of rainfall and its associated risk responsible of the soil degradation. Practically, we calculated simple and combined climatic indices commonly used in Mediterranean countries as a useful metric parameters to describe the climate variability. In fact, the climate variability may induces perenity of the remarkable endemic flora species and the water resources stored in the dams that ensuring the drinking water supply for the Agadir metropolis (9.5 $\mathrm{Mm}^{3}$ ) and the agricultural irrigation for the Issen perimeter (13,000 ha) [15]. Moreover, we mapped the spatial distribution of rainfall and the erosivity in order to determine the susceptible areas to water erosion which will be helpful to manage the erosion risks.

\section{Materials and methods}

\subsection{Data availability}

Climatic data were obtained from the regional climate dataset compiled by the Souss Massaand Tensift Hydraulic Basin Agencies (ABH) and the stations under control of the South-West and High Atlas HCEFLCD (Tab. 1 and 2). The collected rainfall data covering the period of 37 to 50 years. In this study, we analyzed the data covering a satisfactory number of years without missing data. 
Table 1.Characteristics of the rainfall stations in the Issen basin and adjacent zones. (ABH, DREFLCD)

\begin{tabular}{|l|c|c|c|c|c|}
\hline Station & $\begin{array}{c}\text { Lng. } \\
\mathbf{X}\end{array}$ & $\begin{array}{c}{ }^{\mathbf{E}} \\
\mathbf{Y}\end{array}$ & $\begin{array}{c}\text { Lat. } \mathbf{N} \\
\mathbf{Z} \mathbf{( m )}\end{array}$ & $\begin{array}{c}\text { Distance to } \\
\text { the ocean } \\
(\mathbf{K m})\end{array}$ & $\begin{array}{c}\text { Annual } \\
\text { Rainfall } \\
\mathbf{( m m})\end{array}$ \\
\hline A.Elmoumen dam & -9.190 & 30.670 & 635 & 49 & 402.05 \\
\hline Aguenza & -9.153 & 30.751 & 720 & 57 & 253.47 \\
\hline Argana & -9.122 & 30.778 & 771 & 61 & 349.66 \\
\hline Amsoul & -9.069 & 30.842 & 871 & 70 & 193.77 \\
\hline Tizguine & -9.120 & 30.918 & 1329 & 67 & 236.63 \\
\hline Iloudjane & -8.801 & 31.183 & 789 & 98 & 332.15 \\
\hline Aghbar WHA & -8.367 & 30.880 & 1750 & 130 & 537.40 \\
\hline TiziOu-Maacho & -8.968 & 31.058 & 1580 & 84 & 465.48 \\
\hline Ikakern & -8.975 & 30.832 & 1100 & 79 & 222.73 \\
\hline Timlilt & -9.139 & 31.033 & 1350 & 67 & 344.00 \\
\hline Dkhila dam & -9.285 & 30.569 & 232 & 44 & 307.67 \\
\hline Ain Asmama & -9.286 & 30.773 & 1600 & 50 & 473.72 \\
\hline Immouzzer & -9.400 & 30.670 & 1199 & 27 & 540.78 \\
\hline
\end{tabular}

Table 2.Statistical characteristics of the precipitations $(\mathrm{mm})$ in the Issen basin and the adjacent zones (ABH, DREFLCD). A.R: Annual rainfall, S.Div: Standard deviation, Cv: Coefficient of variance, and Q: Quartel

\begin{tabular}{|c|c|c|c|c|c|c|c|c|c|c|c|c|c|}
\hline & 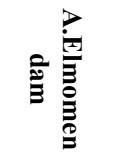 & 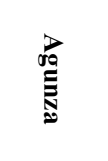 & 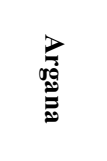 & 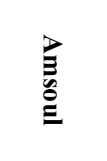 & 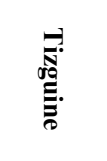 & 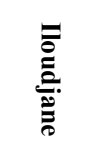 & 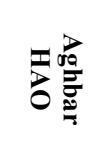 & 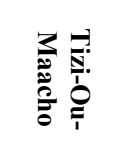 & 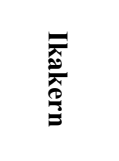 & 車 & 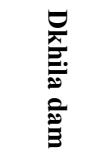 & 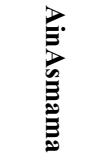 & 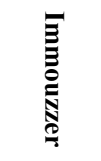 \\
\hline Sep. & 11.57 & 4.48 & 9.96 & 5.16 & 13.75 & 10.45 & 20.50 & 12.33 & 7.43 & 24.6 & 5.07 & 25.12 & 9.16 \\
\hline Oct. & 27.52 & 21.99 & 27.29 & 19.26 & 17.92 & 35.79 & 50.10 & 41.34 & 24.29 & 33.83 & 23.65 & 40.57 & 62.78 \\
\hline Nov. & 78.20 & 46.53 & 54.52 & 31.43 & 29.83 & 36.13 & 73.90 & 59.23 & 52.16 & 25.89 & 57.95 & 82.52 & 85.34 \\
\hline Dec. & 98.97 & 54.98 & 84.40 & 31.58 & 52.75 & 37.12 & 81.90 & 76.40 & 22.21 & 67.36 & 72.86 & 75.13 & 99.07 \\
\hline Jan. & 40.47 & 29.12 & 45.76 & 29.36 & 33.25 & 41.82 & 105.90 & 55.30 & 34.67 & 31.69 & 36.16 & 76.52 & 89.17 \\
\hline Feb. & 65.18 & 36.12 & 61.90 & 25.57 & 40.79 & 39.54 & 58.20 & 66.88 & 24.62 & 42.91 & 41.89 & 71.46 & 83.17 \\
\hline Mar. & 48.90 & 36.09 & 41.87 & 27.00 & 20.46 & 46.02 & 88.90 & 66.18 & 33.63 & 40.21 & 46.60 & 53.96 & 63.21 \\
\hline Apr. & 19.65 & 12.90 & 15.55 & 11.85 & 15.21 & 44.38 & 29.70 & 54.58 & 15.76 & 50.36 & 13.86 & 32.69 & 36.19 \\
\hline May & 8.37 & 4.99 & 5.04 & 5.27 & 2.33 & 20.85 & 15.90 & 17.11 & 2.90 & 16.07 & 7.46 & 8.67 & 10.42 \\
\hline Jun. & 0.99 & 3.00 & 1.13 & 1.07 & 2.42 & 11.17 & 4.70 & 4.20 & 0.67 & 2 & 0.48 & 2.73 & 1.58 \\
\hline Jul. & 0.78 & 0.74 & 1.20 & 2.38 & 0.67 & 3.03 & 2.80 & 1.18 & 0.18 & 0.29 & 0.08 & 0.98 & 0.13 \\
\hline Agu & 1.44 & 2.80 & 1.05 & 3.84 & 7.25 & 5.86 & 4.90 & 10.75 & 4.22 & 8.80 & 1.63 & 3.36 & 0.57 \\
\hline A.R. & 402.06 & 253.74 & 349.66 & 193.77 & 236.63 & 332.15 & 537.4 & 465.48 & 222.73 & 344 & 307.67 & 473.72 & 540.78 \\
\hline Min & 33.8 & 45 & 70.3 & 85 & 167 & 145.1 & 134 & 195.7 & 69 & 219.2 & 38.7 & 154.2 & 154.4 \\
\hline $\operatorname{Max}$ & 1474.7 & 946 & 1801 & 485 & 314 & 519.1 & 1220.5 & 1109.2 & 635.5 & 512 & 928.2 & 977.1 & 1055.6 \\
\hline S.Div & 263.9 & 195.03 & 332.65 & 100.98 & 60.37 & 100.94 & 304.01 & 330.078 & 155.17 & 78.13 & 220.83 & 224.34 & 248.31 \\
\hline $\mathrm{Cv}(\%)$ & 65.00 & 76.86 & 95.14 & 52.11 & 25.51 & 30.39 & 56.57 & 70.91 & 69.67 & 22.71 & 71.77 & 47.36 & 45.92 \\
\hline Q1 & 140.60 & 118.00 & 144.30 & 134.33 & 167.50 & 244.40 & 422.43 & 202.23 & 96.20 & 288.29 & 144.13 & 279.20 & 290.15 \\
\hline Q2 & 361.05 & 223.00 & 268.40 & 201.00 & 236.63 & 332.15 & 564.45 & 322.75 & 214.15 & 351.21 & 255.45 & 446.90 & 401.00 \\
\hline Q3 & 474.40 & 315.50 & 400.63 & 269.75 & 301.50 & 244.40 & 819.27 & 676.78 & 282.25 & 401.60 & 255.45 & 555.85 & 585.75 \\
\hline
\end{tabular}


The temperature is essential data because it is influences the spatial distribution of the vegetation. Table 2 shows the maxima (M), minima (m) and monthly means (Tm) of temperatures in ${ }^{\circ} \mathrm{C}$ of the three stations.

Table 2.Thermal characteristics of the Abdelmomen, Argana and Immouzzerstations.

\begin{tabular}{|c|c|c|c|c|c|c|c|c|c|c|c|c|c|c|}
\hline $\begin{array}{l}\text { Stat } \\
\text { ion }\end{array}$ & $\begin{array}{l}\text { Para- } \\
\text { meter }\end{array}$ & Ja. & Fe. & Ma. & Ap. & Ma. & Jun & Jul. & Ag. & Sp. & Oc. & Nv. & De. & Mean \\
\hline \multirow{3}{*}{ 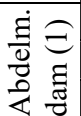 } & M & 25.4 & 22.8 & 24.2 & 28.5 & 28.6 & 34.2 & 39 & 38.4 & 33 & 32.1 & 29.4 & 27 & 30.22 \\
\hline & M & 9.5 & 11.8 & 13 & 15.7 & 16.7 & 20.6 & 25.4 & 25.6 & 21.8 & 19 & 16 & 11 & 17.18 \\
\hline & Tm & 17.5 & 17.3 & 18.6 & 22.1 & 22.7 & 27.4 & 32.2 & 32 & 27.4 & 25.6 & 22.7 & 19 & 24.25 \\
\hline \multirow{3}{*}{ 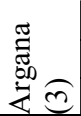 } & M & 18.8 & 21.2 & 24.4 & 27.3 & 29.9 & 32.8 & 40.6 & 41.8 & 36.6 & 30.6 & 24.7 & 19.6 & 29.03 \\
\hline & $\mathbf{m}$ & 1.9 & 3.4 & 5.5 & 7.3 & 9.4 & 14.9 & 15 & 16 & 13.3 & 10.4 & $\begin{array}{l}6.8 \\
\end{array}$ & 2.8 & 8.89 \\
\hline & Tm & 10.4 & 12.3 & 15 & 17.3 & 19.7 & 23.9 & 27.8 & 28.9 & 25 & 20.5 & 15.8 & 11.2 & 21.85 \\
\hline \multirow{3}{*}{ 音 } & $\mathbf{M}$ & 14 & 16 & 19 & 21 & 23 & 29 & 34 & 32 & 27 & 22 & 18 & 16 & 22.58 \\
\hline & $\mathbf{m}$ & 5 & 6 & 8 & 9 & 10 & 14 & 21 & 19 & 16 & 12 & 9 & 7 & 11.33 \\
\hline & $\mathbf{T m}$ & 9.5 & 11 & 13.5 & 15 & 16.5 & 21.5 & 27.5 & 25.5 & 21.5 & 17 & 13.5 & 11.5 & 19.5 \\
\hline
\end{tabular}

\subsection{Data preprocessing}

First, based on the monthly and annual averages of the collected rainfall data the missed values was deduced in order to complete datasets. Secondly, the monthly and annual averages were also used to calculate the climate indices (seasonal regime, monthly drought, deviation-to-mean index (Em), Standardized Precipitation Index (SPI) and rainfall erosivity (R-factor)). Finally, all the annual averages of precipitation and R-factor values were integrated and analyzed in a GIS tool. In fact, mapping rainfall distribution and erosion risk areas was achieved using interpolation krigging method.

\subsection{Rainfall variabilityand trends}

The rainfall deficit, the extent of the drought and its intensity were evaluated using thefollowingindices:

\subsubsection{Monthly drought}

The monthly drought have been assessed based on the total rainfall $(\mathrm{P})$ and the average monthly temperature $(\mathrm{T})$. [16] reported that a month be dry if $\mathrm{P} \leq 2 \mathrm{~T}$. In other hand, [17] indicated that if $\mathrm{P}<3 \mathrm{~T}$ or $\mathrm{P}<4 \mathrm{~T}$ the month is dry.

\subsubsection{Deviation-to-mean index (Em)}

Emis the most used index to estimate the rainfall deficit $[18,19]$ (equation 1). It is positive for wet years and negative for dry years.

$$
E m=X i-X m(1)
$$

Where: $\mathrm{Xi}$ is the cumulative rainfall for year $\mathrm{i}$, and $\mathrm{Xm}$ is the mean annual precipitation 


\subsubsection{Standardized Precipitation Index (SPI)}

The Standardized Precipitation Index (SPI) was developed by Mckee et al. [20]. The SPI have been used to verify humid periods as well as dry periods according to equation 2 .

$$
S P I=(X i-X m) / S i(2)
$$

Where: $\mathrm{Xi}$ is the cumulative rainfall for year $\mathrm{i}, \mathrm{Xm}$ is the mean annual precipitation, and $\mathrm{Si}$ is the standard deviation of the time series annual rainfall.

Effectively, several studies have been used the SPI and defined the different classes of drought severity $[5,18,19,21]$. The negative annual values indicate a dryperiod and positive values indicate a humid period (Tab. 3).

Table 3.Drought degree according toSPI by $[5,18,21]$.

\begin{tabular}{|c|c|}
\hline Drought degree (Class) & SPI Value \\
\hline Extreme humid & SPI $>2$ \\
\hline Severe humid & $1.5<$ SPI $<2$ \\
\hline Moderate humid & $1<$ SPI $<1.5$ \\
\hline Near normal & $-1<\mathrm{SPI}<1$ \\
\hline Moderate drought & $-1<\mathrm{SPI}<-1.5$ \\
\hline Severe drought & $-1.5<\mathrm{SPI}<-2$ \\
\hline Extreme drought & $\mathrm{SPI}<-2$ \\
\hline
\end{tabular}

\subsection{Rainfall Erosivity R-Factor}

The rainfall erosivityis critical factor to assess the soil erosion risks [22].The rainfall erosivityis the product of the energy kinetics of rainy event and its maximum intensity in 30 minutes (IE30) [23].Wischmeier\& Smith [24] provided a complete description of the rainfall erosivity. Arnoldus [25] proposed the Modified Fournier Index (IFM) which combines both the monthly average rainfall for all months of the year $(\mathrm{Rm})$ and the annual average (Xm) (equation 3).

$$
R \simeq I F M=\sum_{i=1}^{12}\left(\mathrm{Rm}^{2}\right) / X m(3)
$$

In this study, due to do not have sufficiently rainfall stations we used linear interpolation to generate the erosivity map. In general, the interpolation method guarantees the minimum variance topredict unknown values.

\section{Results and discussion}

\subsection{Rainfall variability and trend}

\subsubsection{Annual and seasonal average}

The isohyets of the Issen basin range between 100 and $700 \mathrm{~mm}$ (Fig. 3). The analysis of the obtained map reveals a high spatial irregularity of the total precipitation. In general, therainfall increasesfrom the center of the Argana corridor to its borders in relationship with altitude.In addition, the rainfall is lower and relatively homogeneous in the center of the 
basin. The rainfall ranges from 100 to $350 \mathrm{~mm} /$ year in the Timzgadiouine and Argana basin because they are well protected by the high plateaus of the Ida-ou-Bouzia and Ida-ouTanana which brock up the oceanic effects.Furthermore, due to its high altitude, the ancient WHA massif (the snow-covered northern foothills and the Ida-Ou-Tanan plateaus) receives an average precipitation more than $400 \mathrm{~mm} /$ year.

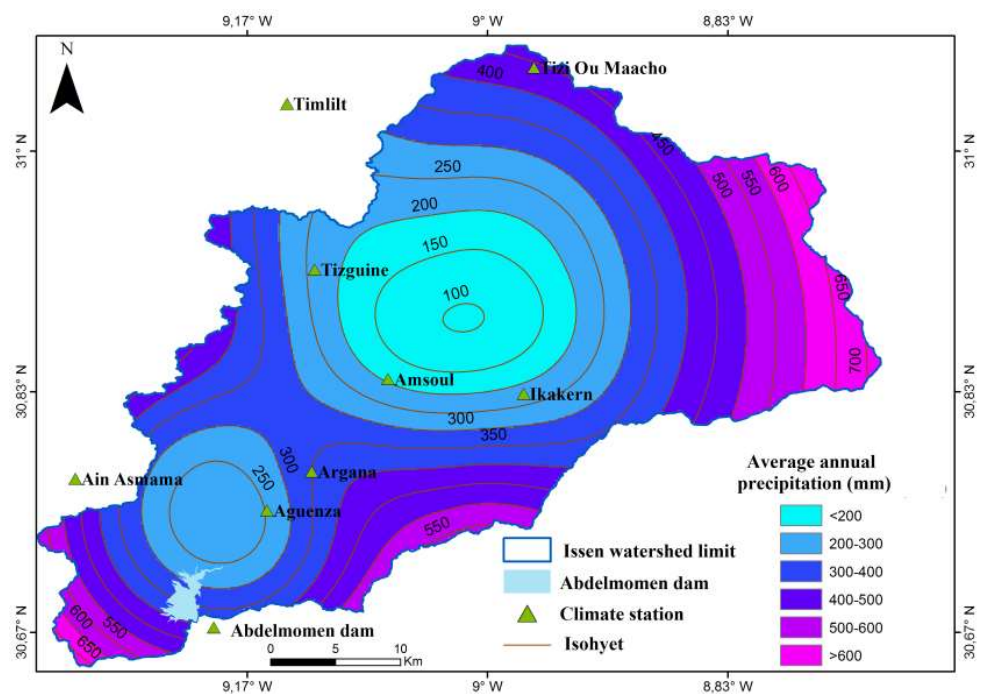

Fig. 3. Spatial distribution of the average annual precipitation in the Issen basin.

During the period 1980-2017 (fig. 4a), the arithmetic mean of rainfall is $302 \mathrm{~mm} /$ year, associated with a coefficient of variation $\mathrm{Cv}=51 \%$ during the 37 years, which reflect a great fluctuation and variability of rainfall. The most remarkable peaks are at 86/87, 95/96 and 09/10 which represent the wettest years, while the peakat2011/12 represents the driest year. The whole basinreceives an average of $141 \mathrm{~mm}$ at winter and half at autumn and spring. However, dry season is summer during it the basin receives the minimum amount of the annual precipitation (Fig. 4b).

The spatial and temporal precipitation variability may affects vegetation development, which increasing soil erosion and then environment degradation [26].

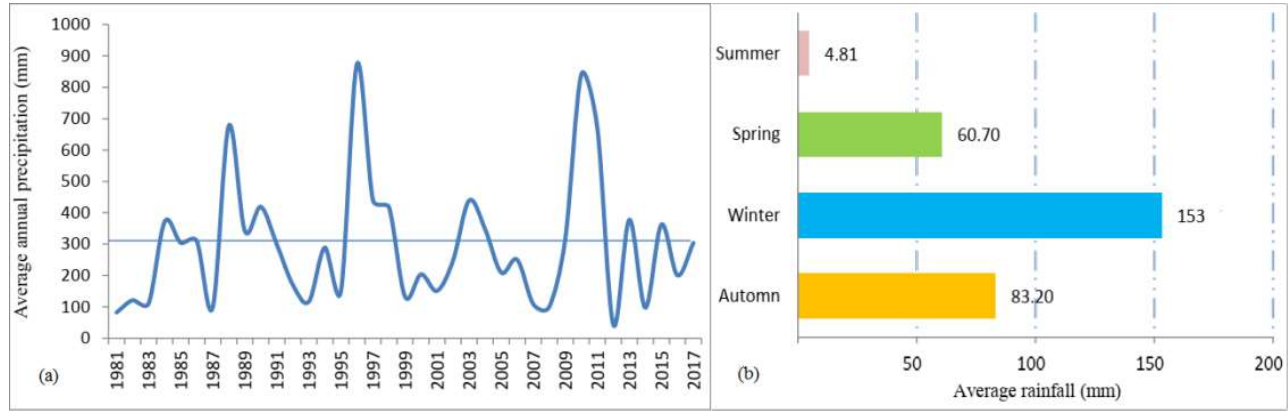

Fig. 4. (a) Interannual variation of rainfall from 1980 to 2017, (b) distribution of average seasonal precipitation in the Issen basin 


\subsubsection{Seasonal regime and monthly drought}

Table 4 resumes the seasonal regime in the Issen basin. The winter season is the wettest, which represents $50 \%$ of the annual total. The maximum winter rainfall is about 271 and $246 \mathrm{~m}$ observed in the Immouzzer and Aghbar stations, respectively. The summer season is the driest, which represents only 1 to $6 \%$ of the annual total.

Table 4. Seasonal regime recorded in the studied stations

\begin{tabular}{|l|c|c|c|c|c|c|}
\hline Stations & $\begin{array}{c}\text { Precipitation } \\
\mathbf{( m m )}\end{array}$ & $\begin{array}{c}\text { Automn } \\
\text { S-O-N } \\
\text { M2 (mm) }\end{array}$ & $\begin{array}{c}\text { Winter } \\
\mathbf{D - J - F} \\
\mathbf{M 1}(\mathbf{m m})\end{array}$ & $\begin{array}{c}\text { Spring } \\
\text { M-A-M } \\
\mathbf{m 1} \mathbf{( m m})\end{array}$ & $\begin{array}{c}\text { Summer } \\
\text { J-Jl-A } \\
\mathbf{m} \mathbf{( m m} \mathbf{( m m})\end{array}$ & $\begin{array}{c}\text { Seasonal } \\
\text { regime }\end{array}$ \\
\hline Immouzzer & $\begin{array}{c}540.78 \\
(100 \%)\end{array}$ & $\begin{array}{c}157.28 \\
(29 \%)\end{array}$ & $\begin{array}{c}271.41 \\
(50 \%)\end{array}$ & $\begin{array}{c}109.82 \\
(20 \%)\end{array}$ & $\begin{array}{c}2.3 \\
(0.5 \%)\end{array}$ & WASS \\
\hline Dkhila dam & 307.69 & $86.67(28)$ & $150.91(49)$ & $67.92(22)$ & $2.19(1)$ & WASS \\
\hline Abdelm. dam & 402.04 & $117.29(29)$ & $204.62(51)$ & $76.92(19)$ & $3.21(1)$ & WASS \\
\hline Ain Asmama & 473.72 & $148.21(31)$ & $223.11(47)$ & $95.32(20)$ & $7.07(2)$ & WASS \\
\hline Agunza & 253.74 & $73.00(29)$ & $120.22(47)$ & $53.98(21)$ & $6.54(3)$ & WASS \\
\hline Argana & 349.67 & $91.77(26)$ & $192.06(55)$ & $62.46(18)$ & $3.38(1)$ & WASS \\
\hline Ikakern & 222.74 & $83.88(38)$ & $81.5(37)$ & $52.29(23)$ & $5.07(2)$ & WASS \\
\hline Amsoul & 193.77 & $55.85(29)$ & $86.51(45)$ & $44.12(23)$ & $7.29(4)$ & WASS \\
\hline Tizguine & 236.63 & $61.50(26)$ & $126.79(54)$ & $38(16)$ & $10.34(4)$ & WASS \\
\hline AghbarWHA & 537.4 & $144.5(27)$ & $246(48)$ & $134.5(25)$ & $12.4(2)$ & WASS \\
\hline Timlilt & 344.01 & $84.32(25)$ & $141.96(41)$ & $106.64(31)$ & $11.09(3)$ & WSAS \\
\hline T.o.Maacho & 465.48 & $112.90(24)$ & $198.58(43)$ & $137.87(30)$ & $16.13(3)$ & WSAS \\
\hline Iloudjane & 332.16 & $82.37(25)$ & $118.48(36)$ & $111.25(33)$ & $20.06(6)$ & WSAS \\
\hline
\end{tabular}

N.B.: Values in brackets indicate seasonal rainfall rates (\%).

The seasonal regime was defined to classify the seasons in descending order of precipitation.The seasonal rainfall regime in the majority of the basin is of the WASS type (Winter-Automn-spring and summer). All the stations representing a summer deficit (m2) and a winter maximum (M1) are subject to the "Soussien" currents in the south-west. The only exceptions are the very northern stations, Timlilt, T.O.Maacho and Iloudjane, that are WSAS type (winter-spring-automn and summer), which show a second maximum (M2) in spring as opposed to autumn and are subject to the "Haouzien" currents of the north-east (Fig. 5). The transition between the two types of regimes occurs in the high basin of Issen at the upstream of the Tizguine station. 


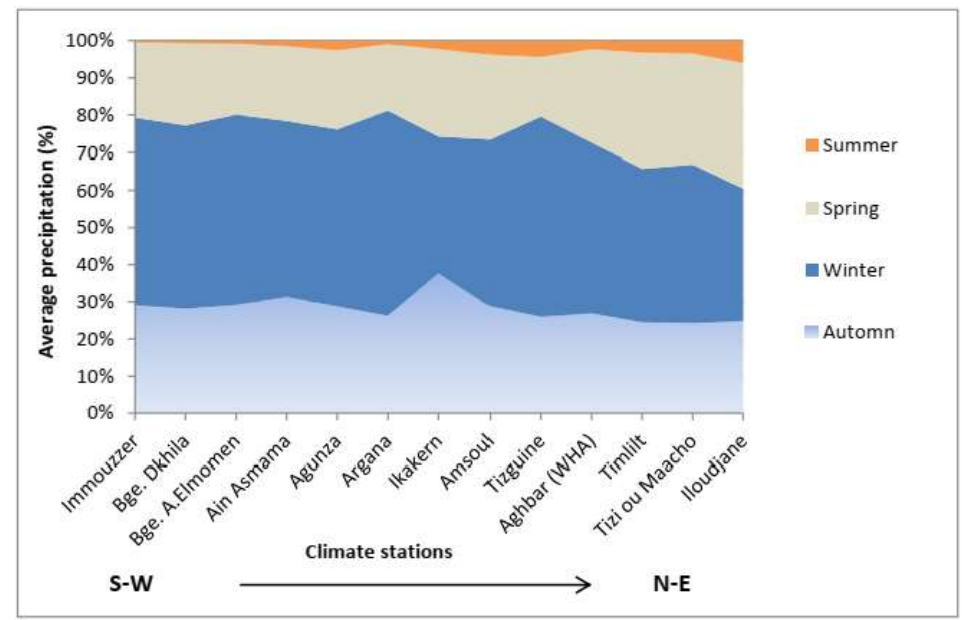

Fig. 5. Seasonal rainfall variation from SW to NE of the Issen river basin.

The ombrothermal diagrams for three stations show that the whole basin is characterized by a drought season lasting 5 to 7 months and a thermal amplitude characterizing semicontinental conditions (cold winter - very hot summer). According to the Embergerclimagram, the study stations are located in the arid bioclimatic zone with a temperate winter and in the semi-arid bioclimatic zone with a cold to worm winter.

\subsubsection{Deviation-to-mean index (Em)}

The results show very unequal spatial and temporal variation of the drought frequency, normal and wet years. The stations of Tizi-Ou-Maacho, Ikakern, Tizguine(upstream part) and Dkhila(downstream part) present an average of drought years of more than $55 \%$, which indicates a tendency to a dryness. The stations of Argana, Abdelmomen, Aguenza, Ain asmama and Immouzzer recorded annual averages of normal rainfall over 20 years. However, a limited number of the stations receivesannual totals above the habitual average with a frequency of wet years over $35 \%$. We notice that more than $40 \%$ of the years are droughty (tab.5). The long period of drought in the study area may affect the vegetation growth and development.

Table 5.Frequency of drought, normal and humid years during 1980-2017

\begin{tabular}{|l|c|c|c|}
\hline Stations & $\begin{array}{c}\text { "DroughtYear" } \\
(\%)\end{array}$ & $\begin{array}{c}\text { "NormalYear" } \\
(\%)\end{array}$ & $\begin{array}{c}\text { "HumidYear" } \\
\text { (\%) }\end{array}$ \\
\hline Immouzzer & 19.75 & 62.96 & 17.28 \\
\hline BgeDkhila & 57.14 & 7.14 & 35.71 \\
\hline Bg. A.elmoumen & 15.15 & 75.76 & 9.09 \\
\hline Ain Asmama & 18.18 & 64.94 & 16.88 \\
\hline Aguenza & 20.59 & 73.53 & 5.88 \\
\hline Argana & 12.94 & 81.18 & 5.88 \\
\hline Amsoul & 27.03 & 59.46 & 13.51 \\
\hline Ikakern & 58.62 & 10.34 & 31.03 \\
\hline Tizguine & 56.25 & 25.00 & 18.75 \\
\hline Aghbar & 50.00 & 10.71 & 39.29 \\
\hline TiziOuMaacho & 66.67 & 6.67 & 26.67 \\
\hline
\end{tabular}




\begin{tabular}{|l|c|c|c|}
\hline Timlilt & 51.43 & 17.14 & 31.43 \\
\hline Iloudjane & 34.62 & 53.85 & 11.54 \\
\hline Mean & $\mathbf{4 0 . 7 0 \%}$ & $\mathbf{4 5 . 7 2 \%}$ & $\mathbf{2 1 . 9 1 \%}$ \\
\hline
\end{tabular}

\subsubsection{Standardized Precipitation Index (SPI)}

Table 6 shows the results of the SPI. For all decennia, normal conditions prevailed in more than $60 \%$ of cases over drought and moisture conditions. The interval period 2010-2017 is still the driest, with moderate or severe drought manifesting in $37.46 \%$ of the cases and in 18 to $27 \%$ of the cases over the other interval periods $1980-89,1990-99$ and $2000-09$. The common drought years are 2000/01 and 2001/02. We also observe that during the 37 years, $26 \%$ of the years are fairly, dry and $13 \%$ are humid. For all stations the rainfall continues to be deficient proving moisture deficit. Labbaci [18] reported a cumulative deficit of 3927.25 $\mathrm{mm}$ during a mean of 25 years in the Site of Biological and Ecological Interest (SBEI) of Ain Asmama(equivalent to an annual deficit of $133 \mathrm{~mm}$ for the dry period).

Table 6. Frequencies (\% of stations/years) of the Standardised Precipitation Index (SPI)

\begin{tabular}{|c|c|c|c|c|c|}
\hline \multirow{2}{*}{ Droughtdegree } & \multicolumn{3}{|c|}{ Moderatedrouhgtperiod } & \multirow{2}{*}{$\begin{array}{c}\text { Severedroughtperiod } \\
2010-2017\end{array}$} & \multirow{2}{*}{ 1980-2017 } \\
\hline & 1980-1989 & 1990-1999 & 2000-2009 & & \\
\hline Extremehumid & 0.17 & 0.20 & 0 & 12.4 & 3.19 \\
\hline Severehumid & 9.01 & 1.00 & 1.12 & 0 & 2.78 \\
\hline Moderatehumid & 10.05 & 9.13 & 9 & 0 & 7.04 \\
\hline Near normal & 61.59 & 70.35 & 69.33 & 50.15 & 62.64 \\
\hline Moderatedrouhgt & 19.18 & 18.23 & 18.20 & 25.32 & 20.23 \\
\hline Severedrought & 0 & 1.10 & 2.31 & 12.00 & 4.81 \\
\hline Extremedrought & 0 & 0 & 0 & 0 & 0 \\
\hline Total & 100 & 100 & 100 & 100 & 100 \\
\hline
\end{tabular}

Figure 6 shows that the Issen Basin has suffered from dry episodes during 1981, 1986, 1992, 1998, 2002, 2006, 2012 and 2014-2017. The analysis of these results indicates a higher frequency of drought years in comparison to the humid years. In addition, the annual droughts occur once or twice every 10 years. In other hands, the drought that lasting 5 years may return after 360 years [27]. 


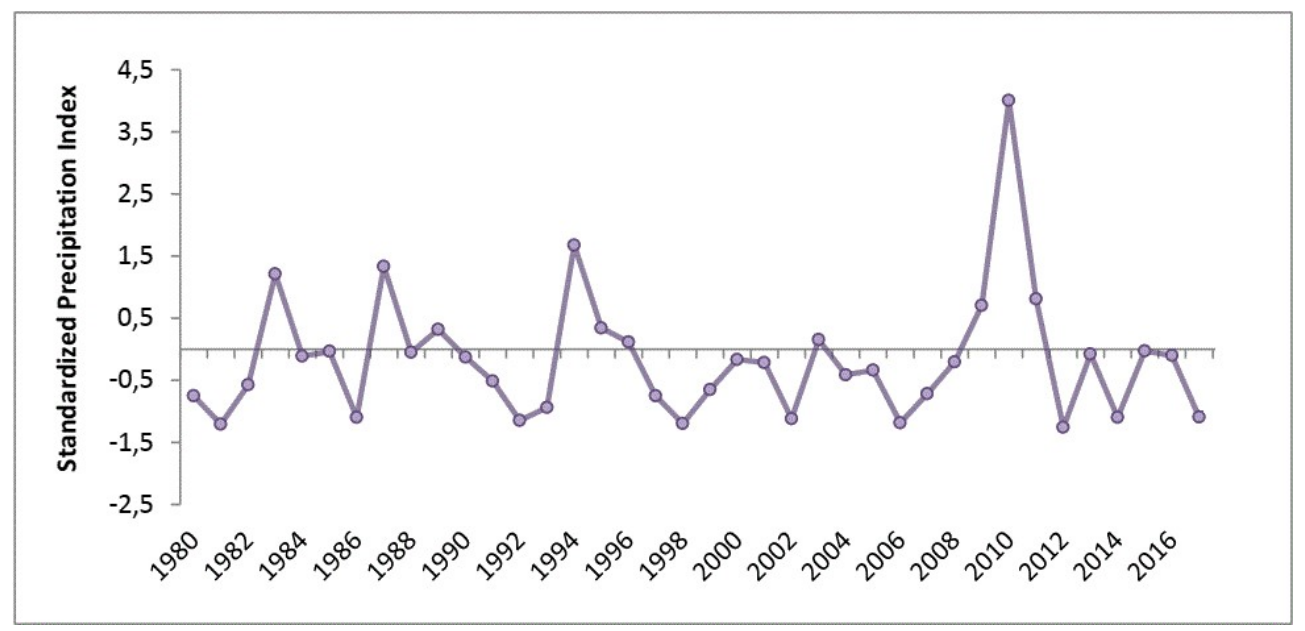

Fig. 6. Standardised Precipitation Index (SPI) in the Issen basin during the period 19802017

\subsection{Rainfall ErosivityR-Factor}

The R-factor considering the role of precipitation for soil erosion modelling: The obtained results show an ascending gradation of values with topography (Fig.6\& tab.6). The erosivity of rainfall naturally progresses from downstream to upstream of the Issen basin. $\mathrm{R}$ values vary between 34 and $80.89 \mathrm{MJ} . \mathrm{mm} / \mathrm{ha}$.h.yr with an average of $47 \mathrm{MJ} . \mathrm{mm} / \mathrm{ha} . \mathrm{h} . \mathrm{yr} .79$ $\%$ of the total area of theIssen basinhave $\mathrm{R}$ values over $41 \mathrm{MJ} . \mathrm{mm} / \mathrm{ha} . \mathrm{h} . \mathrm{yr}$ which contributes to soil loss exceeding the tolerance threshold $(10.4 \mathrm{t} / \mathrm{ha} / \mathrm{yr})[28]$. The low values of R (21 to $40 \mathrm{MJ} . \mathrm{mm} /$ ha.h.yr) are situated in the center of the Argana corridor which includes the two topographic basins of Bigoudine and Timzgadiouine, subject to arid climate. The high values ( $>61 \mathrm{MJ} . \mathrm{mm} /$ ha.h.yr) are attributed to the plateaus region and IdaMahmoud valley, under strong oceanic influence or at high altitudes.

A recent study based on pollen in the marine sediment of the southwest Morocco reported the impact of the climate change and anthropogenic activities on the argan tree ecosystem and soil degradation [1]. 


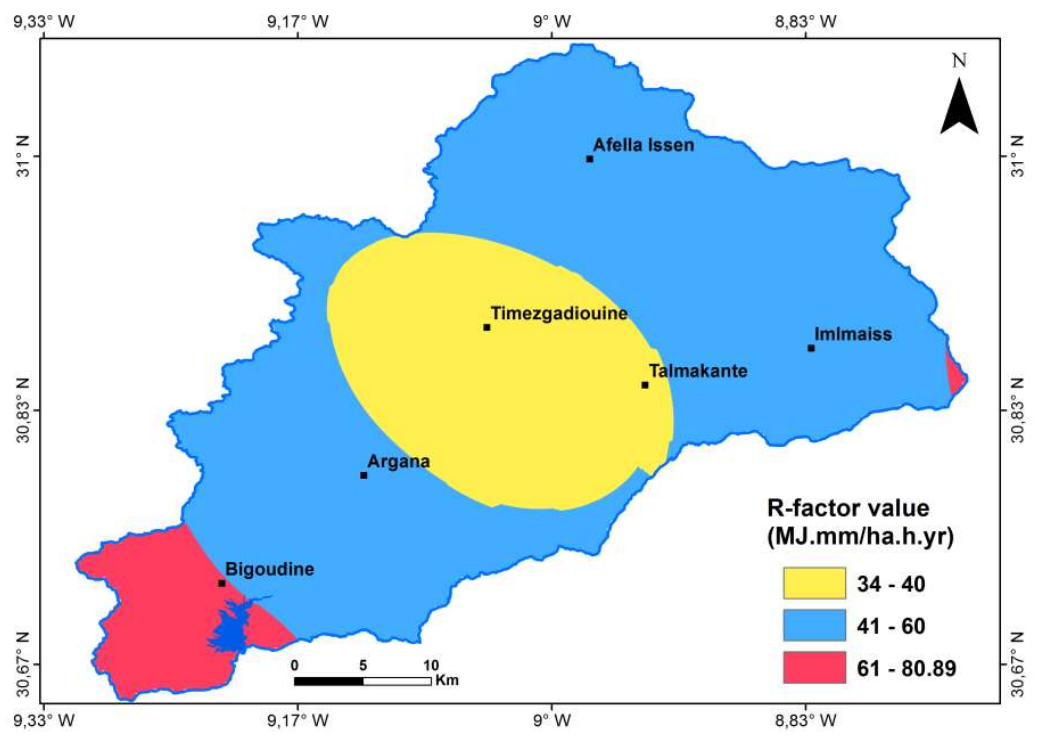

Fig. 7.Spatial distribution of rainfall erosivity (R-factor)

Table7. Conceptual scale for assessing the Fournier index [29]

\begin{tabular}{|c|c|c|c|c|}
\hline Class & $\begin{array}{c}\text { Soil Loss } \\
(\mathbf{t} / \mathbf{h a} / \mathbf{y r})\end{array}$ & $\begin{array}{c}\text { Fournier Index } \\
\text { (MJ.mm/ha.h.yr) }\end{array}$ & Erosion risk & $\begin{array}{c}\text { Area } \\
\mathbf{( \% )}\end{array}$ \\
\hline 1 & $<5$ & $<20$ & Very Low & 0 \\
\hline 2 & $5-12$ & $21-40$ & Low & 21.3 \\
\hline 3 & $12-50$ & $41-60$ & Moderate & 69.6 \\
\hline 4 & $50-100$ & $61-80$ & Severe & 09.1 \\
\hline 5 & $100-200$ & $81-100$ & Very Severe & 0 \\
\hline 6 & $>200$ & $>100$ & Extremely Severe & 0 \\
\hline
\end{tabular}

\section{Conclusions and recommendations}

The study investigated the indicators of drought and climatic aggressiveness in the Issen basin in order to characterize the spatial and temporal variability of precipitation and evaluate the rainfall erosivity. In fact, the record data collected from 13 stations over the study area covering the period 1980-2017 were analyzed using a GIS tools. Thefindings revealed that almost all the studied stations recorded a rainfall below $500 \mathrm{~mm}$ with an arithmetic mean of $302 \mathrm{~mm}$ over the whole basin. The record data of 10 stations (WASStype) reflecting a high aridity and inter-annual and seasonal variability in the study area. In detail, the aridity extends from the beginning of April to the end of October and the dry season duration is about six to seven months per year. Furthermore, the dry periods have been more frequent and remarkable in recent years than humid periods. The analysis of precipitation variabilityusing standardized precipitation index (SPI) indicates moisture deficit.In fact, $70 \%$ of the study area is affected by moderate rainfall erosivity which is responsible of ecosystem degradation. 
The occurrence of a succession of drought, climate events and the rainfall aggressiveness, especially, during the last decade threaten water security, the resilience of the argan trees ecosystem (southwest part of the basin), the quality of the soil and the agricultural sustainability in the study area. In fact, the soil erosion problem can be solved by constructing other dam in the upstream part of the basin which is the most part affected by water erosion. The action will also conserve drinking and irrigation water resources. In addition, it is recommended to regenerate the natural forests such as the argan forest, which is will be helpful to reduce the climate vulnerability. Moreover, extending and serving the researches continuity in the whole area of the Western High Atlas (WHA) can be helpful to figure out the precipitation trend.

\section{References}

[1] X. Zhao, L. Dupontet,\& al., Recent climatic and anthropogenic impacts on endemic species insouthwestern Morocco. Quaternary Science Reviews Volume 221, 1 October 2019, 105889 (2019)https://doi.org/10.1016/j.quascirev.2019.105889

[2] L. Stour, \&A. Agoumi, Sécheresseclimatique au Marocdurant les dernièresdécennies [Climatic Drought in Morocco During the Last Decades]. Hydroécol. Appl., 16: 215 232. (2009)https://doi.org/10.1051/hydro/2009003

[3] M. Hssaisoune, L. Bouchaou, A. Sifeddine, I. Bouimetarhan, \& A. Chehbouni, Moroccan Groundwater Resources and Evolution with Global Climate Changes. Geosciences, 10(2), 81. (2020)https://doi.org/10.3390/geosciences10020081

[4] S. Hammi, V. Simonneaux, M. Alifriqui, L. Auclair,\& N. Montes, Evolution des recouvrementsforestiers et de l'Occupation des sols entre 1964 et 2002 dans la haute vallée des Ait Bouguemez (Haut Atlas Central, Maroc). Impact des modes de gestion. Science etchangementsplanétaires/Sécheresse, 18, 271-277. (2007) https://doi.org/10.1684/sec.2007.0101

[5] C. Faye,A. A. Sow, \&J. B. Ndong, Étude des sècheressespluviométriquesethydrologiques en Afriquetropicale: caractérisation et cartographie de la sècheresse par indices dans le haut bassin du fleuveSénégal. PhysioGéo. Géographie physique etenvironnement, (Volume 9), 17-35. (2015)https://doi.org/10.4000/physio-geo.4388

[6] GIEC,Changementsclimatiques, «Rapport de synthèse» : Contribution des Groupes de travail I, II et III au cinquième Rapport d'évaluation du Grouped'expertsintergouvernementalsurl'évolution du climat.GIEC, Genève, Suisse, 161p, (2014)

[7] M. Alifriqui, O. M'hirit, R. Michalet,\& J. P. Peltier, Variabilité des précipitationsdans le Haut Atlas Occidental marocain. Le climat, 13(1), 11-28. (1995)

[8] P.E. Olsen, D.V. Kent, M. Touhami, \& J. Puffer, Cyclo-magneto and bio-stratigraphic constraints on the duration of the CAMP event and its relationship to the TriassicJurassic boundary. In: Hames, W. E., McHone, G., Renne, P. R. \&Ruppel, C. (eds) The Central Atlantic Magmatic Province: Insights from Fragments of Pangea. AGU, Geophysical Monographs, 136, 7-32, (2003)https://doi.org/10.1029/136GM02

[9] P. Panagos, A. Jones, C. Bosco, \& P.S Kumar, European digital archive on soil maps (EuDASM): preserving important soil data for public free access. International Journal of Digital Earth 4, 434-443, (2011)https://doi.org/10.1080/17538947.2011.596580

[10]B. Jaafar, Etude phytoécologiqueetmorphobotaniqued'une enclave sèche du Haut Atlas occidental Marocain (couloir d'Argana). Thèsedoctorat national, Univ. Cadi Ayyad, Fac. Sci. Semlalia, Marrakech 241p. (1994) 
[11]E.A. El Morjani, M. SeifEnnasr,VA. Elmouden, S. Idbraim, B. Bouaakaz, \&A. Saad, Flood Hazard Mapping and Modelling using GIS applied to the Souss River watershed. R. ChoukrAllah et al. (eds.), the Souss-Massa River Basin, Morocco. «Chapter part of the series The Handbook of Environmental Chemistry pp 1-30», DOI 10.1007/698_2016, Springer International Publishing Switzerland. ungauged Mediterranean catchments. Energy Procedia18: 934-943, (2016)

[12]B. Bouaakkaz, Z.E.A. El Morjani, L. Bouchaou, \& H. Elhimri, Flood risk management in the Souss watershed, E3S Web of Conferences 37, 04005 (2018), published by (EDP Sciences, 2018)https://doi.org/10.1051/e3sconf/20183704005

[13]A. Benabid, \& Y. Melhaoui, Écosystèmesnaturels à arganier (Arganiaspinosa), patrimoine national etuniversel: Bio-écologie, phytosociologie, phytodynamique et ethnobotanique; Restauration et certification. Actes du ler congrès international de l'Arganier (ages 39-47). Agadir, Maroc, (2011)

[14]A. Benabid, Floreetécosystèmes du Maroc. Evaluation etpréservation de la biodiversité. Ibis Press, Paris. (2000)

[15] ABHSM, Optimisation de la gestion de ressources en eau dans le bassin du Souss Massa. Colloquesur la gestion des ressources en eau, mai (2005)

[16]Fr.Bagnouls\&H. Gaussen, Les climatsbiologiquesetleur classification. Annales de géographie. Vol. 66. No. 355. Armand Colin, (1957)

[17]F. Lebourgeois,\& C. Piedallu,.Appréhender le niveau de sécheressedans le cadre des étudesstationnelleset de la gestionforestière à partird'indicesbioclimatiques. Revue forestièrefrançaise. (2005)

[18]A. Labbaci, Thèsedoctorat national, Univ. IbnZohr, Fac. Sci. Agadir, p.237, (2013)

[19] I. Jouilil, K. Bitar, H. Salama,\&al., Sécheressemétéorologique au bassinhydraulique OUM ER RBIA durant les dernièresdécennies. LARHYSS Journal P-ISSN 1112 3680/E-ISSN 2602-7828, 2013, no 12. (2013)

[20] T.B. Mckee, N.J. Doesken,\& J. Kleist, The relationship of drought frequency and duration to time scale. Actes de la 8th Conference on Applied Climatology (Anaheim, Californie), p. 179-184. (1993)

[21]A.Ali,\&T.Lebel, The Sahelian standardized rainfall index revisited. International Journal of Climatolology, vol. 29, p. 1705-1714.(2009)https://doi.org/10.1002/joc.1832

[22] K.Meusburger, A.Steel,P.Panagos, L.Montanarella, \&C.Alewell, Spatial and temporal variability of rainfall erosivity factor for Switzerland. Hydrology and Earth System Sciences, 16, 167-177. (2012) https://doi.org/10.5194/hess-16-167-2012

[23]L.C. Brown\&G.R.Foster, Storm erosivity using idealizedintensity distributions, Transactions of the Asae, 30, 379-386, (1987).

[24] W. H. Wischmeier,\& D. D. Smith, Predicting rainfall erosion losses: A guide to conservation planning. In: USDA Agriculture Handbook 537. Washington, DC: U.S.A, Government Printing Office. (1978)

[25]H.M.J. Arnoldus, An approximation of the rainfall factor in the Universal Soil Loss Equation. In M. deBoot and D. Gabriels (eds), Assessment of erosion. Wiley, chichester. (1980)

[26]R. Cheddadi, M. Nourelbait,O.Bouaissa, J.Tabel, A. Rhoujjati, J. A.López-Sáez,... ,\& H. Lamb, A history of human impact on Moroccan mountain landscapes. African Archaeological Review, 32(2), 233-248. (2015) https://doi.org/10.1007/s10437-0159186- 
[27]A. AGOUMI, Ressources en eau et bassins versants du Maroc : 50 ans de développements (1955-2005), pp. 61. (2006)

[28] Y.Ostovari,A.A. Moosavi, \&H.R. Pourghasemi, Soil loss tolerance in calcareous soils of a semiarid region: evaluation, prediction, and influential parameters. Land Degradation \& Development.1-12. (2020)https://doi.org/10.1002/ldr.3597

[29] K. Oduro-Afriyie, Rainfall erosivitymapforGhana. Geoderma74, 161-166. (1996) 